\title{
The Micronucleus Test: a Method Used in Mutagenicity Testing
}

\author{
Jeanne Adiwinata Pawitan
}

\begin{abstract}
Abstrak
Mikronukleus adalah suatu bangunan bulat di dalam sitoplasma, yang mengandung massa kromatin (DNA). Mikronukleus timbul bila suatu populasi sel yang sedang membelah mengalami patah kromosom yang disebabkan oleh klastogen (sesuatu yang menyebabkan patah kromosom), atau mengalami hilangnya kromosom karena disfungsi spindel mitotik Uji mikronukleus adalah cara cepat untuk menguji mutagenisitas berbagai bahan. Uji ini juga dapat digunakan untuk menilai kerusakan sitogenetik yang disebabkan paparan bahan genotoksik, dan telah terbukti sama sensitifnya dengan pemeriksaan sitogenetik Makalah ini membicarakan tentang penemuan mikronukleus, penyebab terbentuknya mikronukleus dan berbagai aspek uji mikronukleus. Mikronukleus dapat dianalisa pada berbagai sel, secara in vivo pada berbagai individu (manusia, hewan, dan tanaman), atau in vitro pada biakan sel. Sel yang paling sering diperiksa pada uji mikronukleus in vivo adalah eritrosit dan dan pada uji mikronukleus in vitro adalah limfosit. Penggunaan pewarna fluoresens pada uji mikronukleus memberi hasil yang lebih dapat dipercaya, tetapi penggunaannya terbatas, karena waktu fluoresensinya terbatas. Di masa datang, hal ini dapat diatasi dengan cara penghitungan yang menggunakan Flow-sitometer. Pewarnaan mikronukleus yang berdasarkan pewarna Feulgen memberi gambaran yang kurang kontras, sehingga menyulitkan pada penghitungan secara manual, namun hasilnya dapat dipercaya. Dimasa datang hal ini dapat diatasi dengan cara penghitungan otomatik.
\end{abstract}

\begin{abstract}
Micronucleus is a cytoplasmic round body' which contains chromatin mass (DNA). Micronuclei arise when replicating cell populations are subjected to chromosomal breakage by clastogens (agents causing chromosomal breakuge) or to chromosome loss by" mitotic spindle dysfunction. The micronucleus test is a rapid method to test the mutagenicity of various agents. This test can also be used to assess the cytogenetic damage caused by exposures to genotoxic agents, and is proven to be as sensitive as the laborious cytogenetic analysis. This paper discuss the discovery of micronuclei, the cause of micronuclei formation and the various aspects of the micronucleus test. Micronuclei can be analyzed in various cells, in vivo using various individuals (human, animals, and plants), or in vitro using cultured cells. The most frequently screened cells in in vivo micronucleus test are the erjthrocytes, and in in vitro micronucleus test are the lymphocytes. The use of fluorescent stain in micronucleus test gives a more reliable result, but the use is limited, due to the limited fluorescent time. In the future, this can be overcome using Flow-cytometric enumeration. The Feulgen based staining of micronuclei gives a less well pronounced image, thus difficult to score manually, though the result is reliable. In the future this can be overcome using automated enumeration method.
\end{abstract}

Keywards: Polychromatic erythrocytes, binucleated lymphocytes, Giemsa stain, Feulgen-based stain, acridin orange stain, Hoechstpyronin stain, image analysis, automated detection, flow cytometry

The micronucleus is a small distinct extranuclear body in the cytoplasm of a cell. It is spherical in shape with a diameter smaller than $1 / 3$ of the diameter of the main nucleus and has a similar staining quality as the main nucleus. The number of micronuclei varies between one to three per cell (most cells carry only one micronucleus, some carry $2-3$, and cells carrying 4 micronuclei are extremely rare). It is not associated with the main nucleus, ${ }^{1}$ and it contains a chromatin mass (DNA). ${ }^{2}$ Micronucleus persists for a consider- able period of time, and it still persists after one or two cell divisions. ${ }^{1}$

The term "micronucleus test" was originally coined for detecting chromosome breaks induced by mutagens in polychromatic erythrocytes in the bone marrow of rodents. ${ }^{1}$ This test is a rapid method to test the mutagenicity ${ }^{3}$ of various substances (ie. chemicals, ${ }^{4-6}$ drugs, ${ }^{7,8}$ insectisides, ${ }^{9}$ etc.) or hazardous exposures (X-ray radiation, ${ }^{6,10}$ pulsing electromagnetic field, ${ }^{11,12}$ etc.). This test can also be used to assess the 
cytogenetic damage caused by exposures to genotoxic agents, and is claimed to be as reliable as the laborious cytogenetic analysis.

This paper discuss the discovery of micronuclei, the cause of micronuclei formation and the various aspects of the micronucleus test, including the cells screened for in vivo or in vitro micronucleus test, the animals used in the test, and the micronuclei staining and enumeration methods.

\section{THE DISCOVERY OF MICRONUCLEI}

In 1946, Catcheside et al. described additional nuclei (now most likely called micronuclei) which arrised in cells subjected to radiation. Five years later Thoday observed the presence of more than one nucleus in some of the proliferating cells in the root tips of Vicia faba, some time after irradiation. These additional nuclei were smaller in size than the main one, and he called these structures micronuclei or fragment nuclei. ${ }^{\text {cill }}$

\section{THE CAUSE OF MICRONUCLEI FORMATION}

Micronuclei arise when replicating cell populations are subjected to chromosomal breakage by clastogens (agents causing chromosomal breakage) or to chromosome loss by mitotic spindle dysfunction. ${ }^{\text {? }}$ Chromosome breakage will give rise to acentric fragments at mitosis. These fragments, due to the lack of kinetochore will be excluded from the two new daughter nuclei at telophase, and will appear as micronuclei in one or both of the daughter cells. Therefore, it was supposed that micronuclei enclosed acentric chromosome fragments, or, in case of exposure to an agent causing mitotic spindle dysfunction, they might contain whole chromosomes, that had not been incorporated in the main nuclei at cell division.' However, later it is believed that micronuclei can enclose acentric or centric chromosome fragments or whole chromosomes. ${ }^{4}$

\section{THE CELLS SCREENED FOR MICRONUCLEI}

The micronucleus test is now widely used in mutagenicity testing, due to its simplicity. Micronuclei can be induced in vivo or in vitro. Thus, the test can be done in vivo using men, animals such as mice, 2,6 chick, ${ }^{9}$ fish, ${ }^{13}$ newt larvae, ${ }^{5}$ etc. and plants, ${ }^{14}$ or in vitro using cultured cells. $4,8,10,15$ The most frequently screened cells in in vivo micronucleus test are the erythrocytes, and in in vitro micronucleus test. are the lymphocytes.

\section{Screening the Erythrocytes}

The chromosome breaks induced in erythrocytes before maturation, condense themselves into micronuclei (in erythrocytes, they are also called the Howell Jolly bodies). While the main nucleus is ejected during maturation, the micronuclei persist, and can be detected easily. In mice, micronucleated erythrocytes are not selectively removed from the peripheral blood. However, the spleen of human and most animals, removes micronucleated erythrocytes from the circulation. Therefore, the specimen used for scoring micronucleated cells is usually the adult bone marrow. The bone marrow contains a variety of blood cells and their precursors; in bone marrow, the micronuclei are usually scored in polychromatic erythrocytes. However, some investigators used the peripheral blood erythrocytes from splenectomized men, ${ }^{7}$ and some others used cardiac blood erythrocytes of newt larvae (Pleurodeles waltl). ${ }^{5}$

The reactive forms of chromosome-damaging chemicals are often metabolites formed within tissues of exposed individuals. Adult bone marrow has limited activation capacity, and short lived mutagens/carcinogens formed in other tissues may not survive in the circulation, so false-negative results can be obtained. Late in gestation, blood cells develop in the fetal liver, alongside hepatocytes which metabolize premutagens to active forms. A study, exposing 15-16 days pregnant Swiss albino mice to a premutagen and screening the polychromatic erythrocytes, proved that the highest percentage of the micronucleated erythrocytes was found in fetal liver, followed by fetal blood, and the lowest was in maternal bone marrow. ${ }^{6}$ Therefore, for premutagens that need activation, screening in fetal liver or fetal blood is preferable.

The fetal blood contains the erythrocytes, other blood cells and their precursors. Among the erythrocytes, a large number of very young (polychromatic) and young (stippled) erytrhrocytes are present. In the micronucleus test, screening the fetal erythrocytes can be done on the polychromatic erythrocytes only, ${ }^{6}$ or on all erythrocytes. ${ }^{7}$

The highest incidence of polychromatic erythrocytes containing micronuclei in fetal liver was 12-18 hours after the effective exposure to the premutagen, and in both maternal bone marrow and fetal blood was 30 hours after the effective exposure. ${ }^{6}$

The spontaneous incidence of micronucleated erythrocytes in mice (in adult bone marrow, fetal liver, and fetal blood), and in spleenectomized men (peripheral blood) is shown on Table 1. 
Table 1. The spontaneous insidence of micronucleated cells in various individuals

\begin{tabular}{|c|c|c|c|c|c|}
\hline $\begin{array}{l}\text { Specimen } \\
\text { origin }\end{array}$ & Specimen & Type of cell & $\begin{array}{l}\text { Number of } \\
\text { micronucleated } \\
\text { cell }\end{array}$ & $\begin{array}{l}\text { Number of } \\
\text { cells } \\
\text { screened }\end{array}$ & Staining \\
\hline Mouse* & $\begin{array}{l}\text { adult } \\
\text { bone } \\
\text { marrow }\end{array}$ & $\begin{array}{l}\text { polychromatic } \\
\text { erythrocyte }\end{array}$ & $1.6 \pm 0.3$ & 1000 & $\begin{array}{l}\text { May Grun-wald } \\
\text { Giemsa }\end{array}$ \\
\hline Mouse* & $\begin{array}{l}\text { fetal } \\
\text { liver }\end{array}$ & $\begin{array}{l}\text { polychromatic } \\
\text { erythrocyte }\end{array}$ & $4.0 \pm 0.8$ & 1000 & $\begin{array}{l}\text { May Grun-wald } \\
\text { Giemsa }\end{array}$ \\
\hline Mouse* & $\begin{array}{l}\text { fetal } \\
\text { blood }\end{array}$ & $\begin{array}{l}\text { polychromatic } \\
\text { erythrocyte }\end{array}$ & $2.4 \pm 0.9$ & 1000 & $\begin{array}{l}\text { May Grun- } \\
\text { Giemsa }\end{array}$ \\
\hline $\begin{array}{l}\text { Human † } \\
\text { (sp ITP) }\end{array}$ & $\begin{array}{l}\text { peripheral } \\
\text { blood }\end{array}$ & $\begin{array}{l}\text { total } \\
\text { erythrocyte }\end{array}$ & $2.1 \pm 0.3$ & 1000 & Wright \\
\hline $\begin{array}{l}\text { Human } \dagger \\
\text { (sp trauma) }\end{array}$ & $\begin{array}{l}\text { peripheral } \\
\text { blood }\end{array}$ & $\begin{array}{l}\text { total } \\
\text { erythrocyte }\end{array}$ & $2.4 \pm 0.7$ & 1000 & Wright \\
\hline $\begin{array}{l}\text { Human } \ddagger \\
\text { (healthy) }\end{array}$ & $\begin{array}{l}\text { peripheral } \\
\text { blood }\end{array}$ & $\begin{array}{l}\text { cytokinesis } \\
\text { blocked } \\
\text { lymphocyte }\end{array}$ & $4.4 \pm 2.6$ & 500 & $\begin{array}{l}\text { May Grun-wald } \\
\text { Giemsa }\end{array}$ \\
\hline
\end{tabular}

* From Cole et al., ${ }^{6} \dagger$ from Schlegel et al., ${ }^{7} \ddagger$ from Fenech and Morley, ${ }^{10}$ sp ITP = splenectomized for idiopathic thrombocytopenic purpura, sp trauma = splenectomized for trauma.

\section{Screening the lymphocytes}

In human, the difficulty of obtaining bone marrow samples makes the in vivo method impossible to be used in large scale investigations. Since the formation of micronuclei is a general phenomenon in dividing damaged cells, it is also possible to study them in cultured lymphocytes. The first attempt to score micronuclei in lymphocytes was done after the cytoplasm had been destroyed by hypotonic treatment. Countryman and Heddle (1976) and Heddle et al. (1978) found that exposures to X-ray radiation and mitomycin $C$ in vitro lead to a dose-related increase of micronuclei in cultured lymphocytes.

Scoring micronuclei in hypotonically treated preparations, displays certain disadvantages, because the cytoplasm is not preserved and the nuclei tend to clump, making the evaluation difficult. ${ }^{1}$ Moreover, it is often difficult to differentiate real micronuclei from nuclear/cellular debris from other cells, because the cytoplasm of the cell is lacking. Cells with segmentation or fragmentation of the nucleus can easily be regarded as lymphocytes with micronuclei. As the cytoplasm of the cells is destroyed, micronuclei may also be torn from the neighbourhood of the original nucleus. ${ }^{8}$ Therefore, modifications were presented. Iskandar (1979) used mild hypotonic solution consisting of a mixture of physiological salt solution $(0.9 \% \mathrm{NaCl})$ and $0.56 \%$ potassium chloride in a ratio of 9 to 1 , to treat the cultured lymphocytes. The osmotic pressure of this mixture is 285 milliosmol. ${ }^{15}$ The modification preserves the cytoplasm of the lymphocytes. This method can also be applied to fibroblasts. ${ }^{1}$ Hogstedt (1984) cultured the lymphocytes from individuals exposed in vivo, or lymphocytes exposed in vitro, to $\mathrm{X}$-rays, and eliminated the hypotonic treatment. ${ }^{8}$ Using this method, the cytoplasm is also preserved.

The formation of micronuclei requires one cell division to be expressed, consequently the previous methods are very imprecise, since the cells which have undergone only one division, and the micronuclei in them, cannot be identified separately from the total population of lymphocytes. To overcome this problem, cytokinesis of the cells undergoing mitosis is blocked using cytochalasin $\mathrm{B}$, and micronuclei are scored in cytokinesis-blocked cells. Cytochalasin B do not, by itself, produce micronuclei. The cytokinesis-blocked cells are easily recognisable owing to their binucleate 
appearance. This method is simple to perform, as a large number of these cells could be accumulated by adding $3.0 \mu \mathrm{g} / \mathrm{ml}$ cytochalasin B at $44 \mathrm{~h}$ and scoring at 72 h. $^{10}$

According to Fenech et al. (1984), for lymphocytes irradiated in vitro there is a linear relationship between dose radiation and the number of induced micronuclei; the in vivo micronucleus frequency in cytokinesis-blocked lymphocytes from normal individuals is shown in Table $1 .{ }^{10}$

\section{Screening other cells in the in vivo micronucleus} test

Besides the erythrocytes, alternative cells can be used such as the hepatocytes, ${ }^{16}$ the exfoliated epithelial cells found in sputum, ${ }^{17}$ the primary fibroblast derived from Fischer (F344) rats, ${ }^{18}$ etc.

\section{Screening the hepatocytes}

The hepatocytes are most exposed to mutagens, due to the detoxification function of the liver. Especially for premutagens which need activation, scoring the micronucleus in hepatocytes should be very sensitive. In mice, the micronucleated cells increase in correlation with the increasing age (Table2). ${ }^{16}$

Table 2. The proportion of micronucleated hepatocytes in mice of different ages*

\begin{tabular}{lc}
\hline Age (months) & Micronucleated hepatocytes (\%o) \\
\hline 1.5 & 5.9 \\
2 & 8.9 \\
4 & 59.3 \\
7 & 117.0 \\
\hline
\end{tabular}

* Resumed from Uryvaeva and Delone. ${ }^{16}$

\section{Screening the exfoliated cells in sputum}

Micronuclei reflect DNA damage in exfoliated cells and may thus provide a marker of early-stage carcinogenesis. ${ }^{17}$ Micronuclei can be found in exfoliated cells in sputum of heavy smokers, and they can be used to evaluate substances that may reduce lung cancer risk in man. ${ }^{17}$

\section{Screening the fibroblast}

The cytokinesis-block method using cytochalasin B was applied to the primary fibroblast culture. The fibroblast were obtained from Fischer (F344) rats that had been treated by ethylnitrosourea in vivo for 5 hours. The number of micronuclei reached a maximum on the third day. ${ }^{18}$

\section{Screening other cells in the in vitro micronucleus test}

In addition to lymphocytes, other cultured cells can be used such as the L5178Y mouse lymphoma cells, ${ }^{19}$ the Mewo (human malignant melanoma) cells, ${ }^{20}$ the Chinese hamster cell line (V79), ${ }^{4}$ etc.

\section{THE MICRONUCLEI STAINING METHOD}

The micronucleus consists of the same material as the main nucleus; consequently, the staining methods usually used to stain the nuclei, chromosomes, or DNA should be able to stain the micronucleus. Therefore, several staining methods was applied to stain the micronuclei. $2,7,21,24,25$

The methods using modifications of the Romanowsky stain

In 1890 , Romanowsky observed that, by mixing old, mold-covered solution of methylene blue with eosin, a stain was produced which stained the blood cells very well. A purplish-red stain, the methylene azure, which is an oxidation product of methylene blue, is produced when moldy methylene blue is mixed with eosin. In 1891, Malachowski demonstrated that this new metachromatic stain could be obtained consistently by alkalinization of methylene blue and the subsequent addition of eosin, thus making it unnecessary to wait for mold formation to occur. Following these discoveries, numerous modifications was made; these include the stains of Wright (1902) and Giemsa (1902). ${ }^{21}$

The Wright and Giemsa staining method and its modifications (including the May Grunwald-Giemsa staining method) are often used to stain the micronuclei. With these staining methods, the nuclei and micronuclei appear deep purple, red purple, purplish blue or magenta, but the RNA appears the same.

Staining the fetal blood using these staining methods, will stain the RNA within the very young and young erythrocytes. In very young (polychromatic) erythrocytes, the RNA is stained uniformly, and won't give any problem. However, the RNA in young (stippled) erythrocytes (also called reticulocytes) gives a fine stippling appearance. These stipples tend to ag- 
gregate and thus ressemble a micronucleus. ${ }^{2}$ Therefore, the Romanowsky-based staining methods is used only to screen the polychromatic erythrocytes; scoring in the stippled erythrocytes is unreliable, due to the presence of numerous RNA aggregates. ${ }^{2}$

Staining the lymphocytes using these staining methods, will also stain the dense lysosomes that appear as tiny reddish-purple granules called the azurophilic granules. ${ }^{21,22,23}$ Roughly $10 \%$ of lymphocytes contain these granules. ${ }^{23}$ It is difficult to distinguish the reddish purple azurophilic granules from the micronucleus, so scoring in the lymphocytes using these staining methods will give a higher frequency of micronuclei, compared to scoring using a DNA specific (Feulgen) stain (Table 3).

Table 3. The proportion of micronucleated cells stained with Giensa or Feulgen-Congo red, in binucleated lymphocytes, after treatment*

\begin{tabular}{lcl}
\hline Treatment & $\% \circ$ & Staining method \\
\hline Irradiation & $37.7+36.5$ & Giemsa \\
MMS $25 \mu \mathrm{g} / \mathrm{ml}$ & $44.7+23.9$ & Giemsa \\
Irradiation & $23.5+2.1$ & Feulgen-Congo red \\
MMS $25 \mu \mathrm{g} / \mathrm{ml}$ & $22.7+10.5$ & Feulgen-Congo red \\
\hline
\end{tabular}

MMS = methyl methane sulphonate, * resumed from Castelain et al. $^{25}$

\section{The staining methods which can differentiate DNA} from other substances

To increase the efficiency of the micronucleus test, screening in each age population of erythrocytes is needed. ${ }^{2}$ For this reason, staining methods which can differentiate DNA from RNA are used; these methods use the fluorescent stain e.g. the acridine orange, ${ }^{7}$ Hoechst 33258-pyronin Y, and Hoechst 33342thiazole orange. ${ }^{24}$ In addition, the Feulgen-based staining methods can also be used, e.g. the Feulgen-Congo red (FCR) staining method which was applied to stain the binucleated lymphocytes. ${ }^{25}$

\section{The staining methods using fluorescent stain}

The acridine orange staining is performed by immersion of slides for 5 min in $\mathrm{pH} 7.4$ sodium phosphate buffer ( $1 \%$ by weight) containing $0.02 \mathrm{mg}$ of acridine orange per $\mathrm{ml}$, followed by a $10 \mathrm{~min}$ rinse in $\mathrm{pH} 7.4$ phosphate buffer. Slides are then wet mounted and examined by fluorescent microscopy using a Zeiss fluorescein isothiocyanate filter. Under these condi- tions, RNA fluorescès red, and DNA (micronuclei) green-yellow. ${ }^{7}$

The Hoechst 33258-pyronin Y stain consists of Hoechst 33258 which stains only DNA, and pyronin $Y$ which stains both DNA and RNA. Stained slides are examined by fluorecent microscopy. Excitation of pyronin with green light $(546 \mathrm{~nm})$ causes both RNA and DNA to fluoresce orange, while hoechst stained DNA (but not RNA) fluoresces brilliant blue under UV $(360 \mathrm{~nm})$ excitation. The RNA- negative (mature) erythrocytes are visualized using dim brightfield (Koehler) illumination. ${ }^{2}$

The Hoechst 33342-thiazole orange stain consists of thiazole orange that is used for discrimination between polychromatic and normochromatic erythrocytes, and Hoechst 33342 that is used to detect the micronucleus. ${ }^{24}$

The use of fluorescent stains needs fluorescent mycroscopy to examine the slides. In addition, screening must be done quickly, due to the limited fluorescent time. Consequently, the use of fluorescent stains in screening micronucleated cells is limited, though the result is more reliable.

\section{The Feulgen-based staining method}

The Feulgen-Congo red (FCR) staining method combines the Feulgen stain which stains only DNA and Congo red which stains the cytoplasm. The FCR stained cells were less intensively stained than the Giemsa stained cells. Therefore, the FCR stained micronuclei were less well pronounced. ${ }^{25}$ Consequently, it is difficult to score manually, though the result is reliable.

\section{THE MICRONUCLEI ENUMERATION METHOD}

\section{Manual enumeration}

The proportion of micronucleated cells is relatively low, consequently, a lot of cells have to be screened (500-2000 cells). Screening a large number of cells manually is annoying and takes a lot of time. Besides, staining using fluorescent stains which is more reliable, should pose a problem in manual enumeration, due to the limited fluorescent time.

\section{Flow-cytometric enumeration}

Theoretically, Flow-cytometric enumeration can be done on fluorescent stained cells. A flow-cytometric enumeration to determine the frequency of micronucleated polychromatic erythrocytes was done using 
Hoechst 33342 -thiazole orange stain. ${ }^{24}$ It is claimed that up to 70,000 polychromatic erythrocytes can be analyzed in less than 10 minutes; this corresponds to 150-3,000 micronucleated polychromatic erythrocytes, $90-95 \%$ of which are true events as determined with a fluorescence microscope after sorting. ${ }^{24}$

\section{Automated enumeration using computer based Image analysis}

The automated enumeration system for micronuclei scoring consisted of a Magiscan MD image processor interfaced to a microscope with a black/white 6-bit TV camera with Chalnicon tube and connected to a motorized eight-slide stage. Automatic scoring combined with visual inspection was compared to manual scoring in Giemsa and Feulgen-Congo red stained cells. The result revealed that $59-86 \%$ of all automatically clasified binucleated cytokinesis-blocked cells were correctly classified. Although some micronucleus were overlooked during automated scoring, on average, similar micronuclei frequencies were obtained with automated and manual scoring. ${ }^{25}$ Using this automatic system, it is possible to scan a high number of cells overnight. This will be particularly usefull in scanning the feulgen-based stained cells, in which the micronuclei are difficult to detect manually, due to their pale appearence.

\section{CONCLUSION}

The micronucleus test is a rapid method to test the mutagenicity of various agents. Micronuclei can be analyzed in various cells, in vivo using various individuals (human, animals, and plants), or in vitro using cultured cells. The most frequently screened cells in in vivo micronucleus test are the erythrocytes, and in in vitro micronucleus test are the lymphocytes.

The use of fluorescent stain in micronucleus test gives a more reliable result, but the use is limited, due to the limited fluorescent time. In the future, this problem can be overcome using Flow-cytometric enumeration.

The Feulgen-based staining of micronuclei gives a less well pronounced image, thus difficult to score manually, though the result is reliable. In the future this problem can be overcome using automated enumeration method.

\section{REFERENCES}

1. Iskandar $O$. The micronucleus test [dissertation]. Jakarta : Univ. of Indonesia, 1981.
2. MacGregor JT, Henika PR, Whitehand L, Wehr CM. The fetal blood erythrocyte micronucleus assay: clasification of RNA-positive erythrocytes into two age population by RNA aggregation state. Mutagenesis 1989; 4:190-9.

3. Lu FC. Basic toxicology. 2nd ed. Washington: Hemisphere, 1991.

4. Nusse M, Viaggi S, Bonatti S. Induction of kinetochore positive and negative micronuclei in V79 cells by the alkylating agent diethylsulphate. Mutagenesis 1989; 4:174-8.

5. Gauthier L, Levi Y, Jaylet A. Evaluation of the clastogenicity of water treated with sodium hypochlorite or monochloramine using a micronucleus test in newt larvae (Pleurodele walt1). Mutagenesis 1989; 4:170-3.

6. Cole RJ, Taylor NA, Cole J, Arlett CF. Transplacental effects of chemical mutagens detected by the micronucleus test. Nature 1979; 277:317-8.

7. Schlegel R, MacGregor JT, Everson RB. Assessment of cytogenetic damage by quantitation of micronuclei in human peripheral blood erythrocytes. Cancer Res 1986; 46:371721.

8. Hogstedt B. Micronuclei in lymphocytes with preserved cytoplasm, a method for assessment of cytogenetic damage in man. Mutat Res 1984; 130:63-72.

9. Jena GB, Bhunya SP. Thirty day genotoxicity study of an organophosphate insecticide, monocrotophos, in a chick in vivo test system. In-Vivo 1992; 6:527-30.

10. Fenech M, Morley AA. Measurement of micronuclei in lymphocytes. Mutat Res 1985; 147:29-36.

11. Khalil AM, Gassem W. Cytogenetic effects of pulsing electromagnetic field on human lymphocytes in vitro: chromosome aberrations, sister-chromatid exchanges and cell kinetics. Mutat Res 1991; 247:141-6.

12. Valjus J, Norrpa H, Jarventaus H, Sorsa M, Nykyri E, Salomaa S, et al. Analysis of chromosomal aberrations, sister chromatid exchanges and micronuclei among power linesmen with long-term exposures to $50-\mathrm{Hz}$ electromagnetic fields. Radiat Environ Biophys 1993; 32:325-6. Abstract.

13. al Sabti K. Monitoring the genotoxicity of radiocontaminant in Swedish lakes by fish micronuclei. Cytobios 1992; 70(281):101- 6. Abstract.

14. Ma TH, Sandhu SS, Peng Y, Chen TD, Kim TW. Synergistic and antagonistic effects on genotoxicity of chemicals commonly found in hazardous waste sites. Mutat Res 1992; 270:71-7.

15. Iskandar $O$. An improved method for the detection of micronuclei in human lymphocytes. Stain technology 1979; $54: 221-223$

16. Uryvaeva IN, Delone GV. Otsenka urovnia nakoplennykh s vozrastom i indutsirovannykh geneticheskikh povreshdenii $\checkmark$ kletkakh pecheni po produktsii mikroiader. Ontogenez 1992; 23:370-8. English abstract.

17. van Poppel G, Kok FJ, Hermus RJ. Beta-carotene supplementation in smokers reduces the frequency of micronuclei in sputum. Br J Cancer 1992; 66:1164-8.

18. Khan MA, Heddle JA. Optimization of the concurrent assay for gene mutation and chromosomal aberration in vivo: expression time in rats. Environ Mol Mutagen 1992; 20:16571.

19. Dearfield KL, Harrington-Brock K, Doerr CL, Parker L, Moore MM. Genotoxicity of three pyridine compounds to 
L5178Y mouse lymphoma cells. Mutat Res 1993; 301:5763.

20. Fuhrmann C, Streffer C, Muller WU, Becker U. Micronucleus assay prediction and application optimized by cytochalasin B- induced binucleated tumor cells. Strahlenther Onkol 1992; 168:603-9. Abstract.

21. Wintrobe MW. Clinical hematology. 5th ed. Philadelphia: Lea \& Febiger, 1961.

22. Fawcett DW. Bloom and Fawcett (a textbook of) Histology. 11 th ed. Japan: Igakushoin/Saunders, 1986.
23. Cormack DH. Ham's histology. 9th ed. Philadelphia: JB Lippincott, 1987.

24. Grawe J, Zetterberg G, Amneus H. Flow-cytometric enumeration of micronucleated polychromatic erythrocytes in mouse peripheral blood. Cytometry 1992; 13:750-8.

25. Castelain P, Van Hummelen P, Deleener A, Kirsch-Volders M. Automated detection of cytochalasin-B blocked binucleated lymphocytes for scoring micronuclei. Mutagenesis 1993; 8:285- 93. 